\title{
方鉛鉱の濡れの性質についで
}

\author{
正会員斎藤浩 三**
}

\section{Wetting Characteristics of Galena}

Kōzō SAITO

The author have investigated on wetting characteristics of galena produced from Japan by means of spheroidal drop method. Advancing contact angles were affected with roughness and chemical composition of samples. A formation of new crystal on the surface of depressed galena was determined by electron diffraction method, and the wetting characteristics depend on nature of the crystal. The main results obtained are as follows :-

(1) Contact angle depends on roughness of surface, and its value of fresh cleavage is greater than that of emery polished surface.

(2) Contact angle is affected with chemical composition and its value decreases especially with increasing of silver content.

(3) Contact angle of the sample preconditioned in potassium permanganate solution decreases linearly with increasing of concentration of the solution.

(4) Surface of galena was slightly oxidized by potassium permanganate solution, and then manganese oxide hydrate $\mathrm{MnO}_{2} \cdot(\mathrm{O} \sim 1) \mathrm{MnO} \cdot n \mathrm{H}_{2} \mathrm{O}$ was found on it by means of electron diffraction.

\section{1. 緒}

言

方鉊鉱は最も重要な鉛の原料鉱物であつて, しばしば 閃亜鉛鉱とともに大きな鈗床を形成し，また他の種々の 金属鉱床の随伴鉱物として普遍的に産する。したがつて 方鉛鉱には生成条件や随伴鉱物を異にするものが多く， これらの間の物理性, 化学性にはある程度のかたよりの 存在が期待される。

筆者は本邦産方鉛鉱について各種の実験を行ない，微 量成分の含量と 2,3 の物性との間に規則性が存在するこ とを見出し，これらについてはすでに報告した ${ }^{1,2)}$ 。今 回は濡れの直接的な尺度として接触角を測定した結果, これが方鉛鉱の化学組成あるいは鉱物表面の物理的性状 に影響され，さらに抑制郕を作用させた場合には著しい 変化を示すことが認められた。また，抑制剂を作用させ た場合には鉱物表面に新しい結晶体が生成されることを 電子回折法で確認し，抑制剤の作用機構を明らかにする ことが出来たので，実験結果の要点を報告する。

なお，本実験に用いた試料の化学成分および鉱物学的 性状については，さきの報告1,2)を参照されたい。

\section{2. 試料および試験方法}

試料湭朝日，茂住，杤洞一 $200 \mathrm{~m}$, 尾太および田老産 のもので，第1表のようにいずれも $a(100)$ を主とする 正六面体式の晶相を示し, 杤洞 $-200 \mathrm{~m}$ 産試料は $a$ の隅

* 昭和 36 年 2 月 21 日受理, 昭和 35 年日本鉱業会秋季大会にて講演

** 三井金属鉱業株式会社中央研究所
角を 0 (111) で久いている。また供試料の色調, 条痕色 および光沢の程度には多少の差異が認められる。これら 試料の辟開面は肉眼的には鏡面のような平滑さを有する もので，測定は壂開直後の新鮮な面およびこれを $0 / 3$, 0/4 エメリーペーパで乾式研摩したものについて行なつ た。

接触角の測定方法はいろいろ発表されているが，その 主なものは光反射法, 挔大映像法, 傾板法, 回転円筒法, 液滴 (気泡) 形状法, 毛管上昇法, 圧力変位法，祀じり ばかり法，浸透速度法などであるわ。本試験では操作が 簡単で比較的精度の高い拡大映像法 $\left.{ }^{4}, 5\right)$ を適用した。

各試料についてそれぞれ 20 個の小片を準備し， 1 小 片に扔いて 2 点の測定を行い合計 40 回の測定結果を集 計した。充分に細く引き伸した清浄なガラス棒を用いて 直径がほぼ $1.5 \mathrm{~mm}$ の水滴を試料面にお直ちに測定を 行なつた。映像桩大装置の光軸と一致するように試料小 片を固定, 水滴の映像を約 30 倍に拡大してスクリーン 上に映写した。この桩大映像はスクリーン上の紙に直ち にうつしとり, 水滴の高さ $h$ と半径 $a$ を測定して,

第 1 表 供試料の外観的性状

\begin{tabular}{|c|c|c|c|c|c|}
\hline 試 & 料 & 色 調 & 条痕 & 金属光沢 & 結 \\
\hline 朝 & 日 & 鋼灰色 & 暗黒色 & 普 通 & $a$ の良結晶, 径 5 10m m \\
\hline 茂 & 住 & 暗鋼色 & 暗黒色 & 普 通 & 径 $5 \mathrm{~mm}$ 程度の $a$ \\
\hline 杤洞 & $-200 m$ & 暗鐦色 & 帯灰黒色 & 弱 & 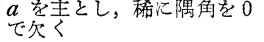 \\
\hline 尾 & 太 & 鋼质色 & 暗黒色 & 強 & 径数 $\mathrm{mm} \sim 8 \mathrm{~mm}$ の $a$ \\
\hline 田 & 老 & 暗鋼色 & 黑 色 & 普 通 & 径 $5 \mathrm{~mm}$ 程度の $a$ \\
\hline
\end{tabular}


$\theta_{a}=2 \tan ^{-1}\left(\frac{h}{a}\right)$ から接触角を算出した。このようにし て得られた值はすべて前進接触角 $\theta_{a}$ を与えるが，以下 これを単に接触角と呼ぶ。

測定面に抑制剤を条件付与する場合には面の物理的性 状を一定にするため畭式研摩したものを用いた。条件付 与は所要濃度の溶液に $30 \mathrm{~min}$ 浸漬, 蒸留水でよく洗浄 の後, 水滴を沪紙で吸いとり自然乾燥してから測定を行 つた。条件付与する場合にはすべて朝日産試料を用いた。

\section{3. 測 定 結 果}

\section{$3 \cdot 1$ 新鮮面の接触角}

同一試料においても測定值はほとんど一致することな くあるばらつきを示している。第2 表の測定結果のよう に最大と最小との間には約 20 のひらきがある。しかし 同一試料について数多くの測定を行うと算術平均值付近 に頻度最大があらわれることが経験的に知られたので以 下この平均值をもつてその試料の值とした。第 2 表の測 定値を検討すると朝日, 茂住, 栃洞 $-200 \mathrm{~m}$, 尾太, 田 老の順に減少していて，しかも新鮮䢃開面はいずれの試 料でもエメリ一研摩面より大きな接触角を与えている。

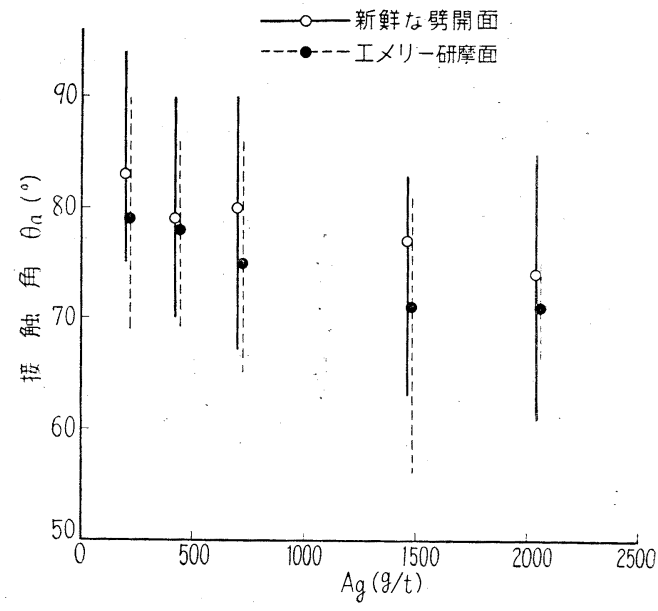

第1図 $\mathrm{Ag}$ と接触角

第 2 表 新鮮面の接触角 $\left({ }^{\circ}\right)$

\begin{tabular}{|c|c|c|c|c|c|c|}
\hline 测 定 面の種 & 別 & 朝 日 & 茂，住 & 栃 & 尾 太 & 田老 \\
\hline 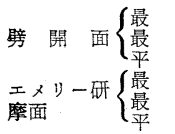 & $\begin{array}{l}\text { 大 } \\
\text { 少 } \\
\text { 均 } \\
\text { 柰 } \\
\text { 小 } \\
\text { 均 }\end{array}$ & $\begin{array}{l}94 \\
75 \\
83 \\
90 \\
69 \\
79\end{array}$ & $\begin{array}{l}90 \\
70 \\
79 \\
86 \\
69 \\
78\end{array}$ & $\begin{array}{l}90 \\
67 \\
80 \\
86 \\
65 \\
75\end{array}$ & $\begin{array}{l}83 \\
63 \\
77 \\
81 \\
56 \\
71\end{array}$ & $\begin{array}{l}85 \\
61 \\
74 \\
75 \\
66 \\
71\end{array}$ \\
\hline
\end{tabular}

第3 表 ガラスセル浮選産物の分光定性結果

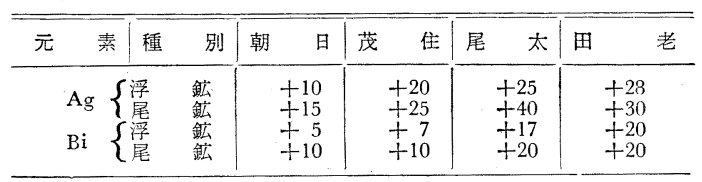

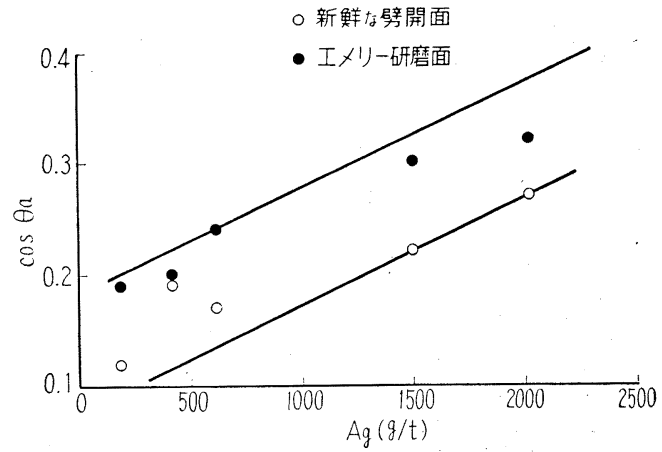

第2図 $\mathrm{Ag}$ と $\cos \theta a$ との関係

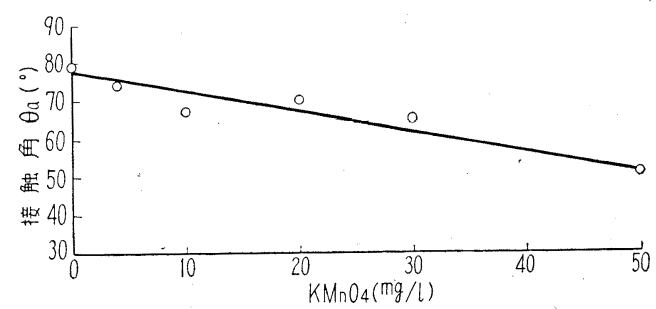

第 3 図 $\mathrm{KMnO}_{4}$ 溶液濃度と接触角の関係

この接触角の大小の序列は含銀量と関係があり,第 1 図 の通り銀量の増加にしたがつて明らかに接触角の減少が 認められる。また銀量と $\cos \theta a$ は第 2 図の通り比例関 係を示す。

この場合接触角の測定が特定の䢃開面で行われている ので，上述の関係が浮選現象まで拡張出来るものか否か を次のようにして検討した。すなわち，ガラスセル浮選 機を用い朝日，茂住，尾太および田老試料の純水中の浮 選を行ない，その産物をそれぞれ分光分析に供した。そ の結果は第 3 表の通り，いずれの試料においても尾鉱の 銀量が高く，蒼鉛についても銀と同様の傾向が認められ た。したがうて，実際の浮選現象中でも銀の少ない方鉛 鉱が容易に浮遊し，既述の接触角の測定結果とよく調和 する。

\section{$3 \cdot 2$ 過マンガン酸カリ溶液を作用させた面の接触角}

方鉊鉱の代表的抑制剂である過マンガン酸カリの効果 は $20 \mathrm{mg} / l$ 付近からあらわれはじめ, $50 \mathrm{mg} / l$ では充分 量の捕収剂を用いてもほぼ完全に抑制されるに至る*っ の抑制作用の原理は電子回折結果より明らかなように鉱 粒表面における新結晶の生成と関連ずけて説明されるも のであるが**：過マンガン酸カリを作用させた面の接触 角を測定して抑制効果を支配する直接的現象を見出そう とするものである。

過マンガン酸カリ溶液に試料小片を浸漬すれば明らか

* 方銛鈗の浮選に関する基楚的な実験結果は本報告とは别に発表す る予定である。

** 方銛鉱住対する各種条件剤の作用機構については電子回折を行つ て，いくつかの新しい事実を見出した。この電子回折試験の結果 はとりまとめて別化発表する。 


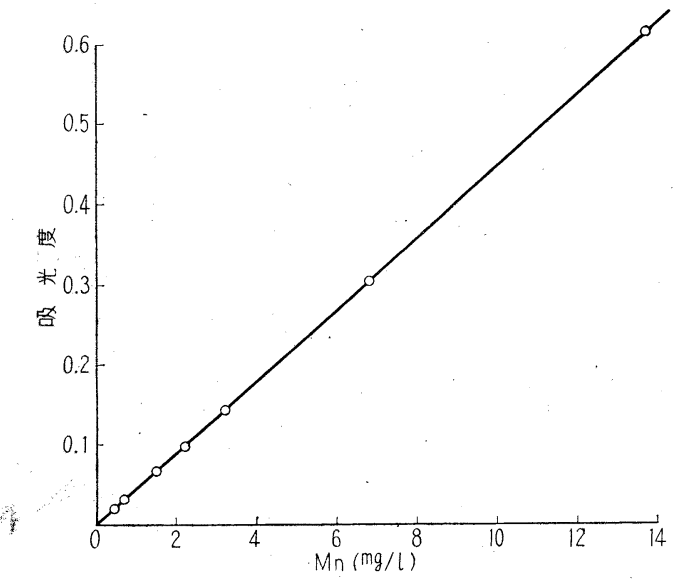

第 4 図 Mn の検量線

に色調の変化が認められ，10mg/l で金属光沢を失い， $20 \mathrm{mg} / l$ で僅かに変彩, これ以上の濃度では金属光沢を 完全に失い，かつ著しく変彩するに至る。このような面 の測定結果は第 3 図の通り, 過マンガン酸カリの濃度の 増加に従つてほぼ直線的に減少する。これは，方鉛鉱の 表面に新たに生成された結晶体が次第に厚さを増して行 くためであろう。

\section{4. 過マンガン酸カリ溶液を作用させた 場合の表面変化}

\section{1 化学分析結果}

過マンガン酸カリ溶液に試料を浸漬すると, 明らかに 接触角が減少し, したがつて鉱物表面には何らかの変化 を生じていることが期待される。この点について浸漬前 後における過マンガン酸カリ溶液の濃度測定および試料 の $\mathrm{Mn}$ の定量を行なつてみた。

朝日試料 $(-100+200 \mathrm{mesh})$ の $2 \mathrm{~g}$ を所要蜄度の過 マンガン酸カリ溶液 $50 \mathrm{cc}$ 中に $30 \mathrm{~min}$ 浸清の後, 試料 を純水 $20 \mathrm{cc}$ で 5 回洗浄してから試料の Mn を定量す ると同時に, 条件付与前後の溶液濃度を測定した。この 浸液操作は恒温室 $\left(20^{\circ} \mathrm{C}\right)$ で行われ，実験に用いた朝日 試料には全く Mn を含まないことをあらかじめ確めてお いた。

Mn の定量には，はじめ過硫酸アンモン法6)を適用し たが結果が安定しないので，方法をいろいろ検討した結 果, 次に述べる過沃素酸カリ法が良いと分つた。すなわ ち, 上記浸液操作後の試料をビーカーにとり, 水約 $5 \mathrm{cc}$ にてしめらせ，濃硝酸 $20 \mathrm{cc}$ を加えて加熱分解する。 この分解が終了し白色沈搌の生成が多くなり出してから 硫酸 (1:1) 10cc を加え, さらに加熱をつゔけて白煙を 発生させる。氷冷してから水約 10cc 学添加し, さらに 氷冷を行なつてから沈澱を No. 2 沪紙で汇別し，少量
の水で洗滌する。沪別後の液量を約 $25 \mathrm{cc}$ としてからこ れに混酸* $10 \mathrm{cc}$ ，過沃素酸カリ $0.2 \mathrm{~g}$ を加え加熱沸騰 させる。発色後さらに約 $3 \mathrm{~min}$ 間沸騰をつづけ. 泠却後 水で $50 \mathrm{cc}$ に稀䆏する。分光光電光度計（日立製）を用 い，水を対象液として $525 \mathrm{~m} \mu$ の波長で吸光度を測定し 亦らかじめ作成した第 4 図の検量線から Mn の量を求 めた。溶液の場合にはその 50 100cc に濃硝酸 $5 \mathrm{cc}$, 過 酸化水素 1 滴を加えて脱色し, 加熱濃縮してほとんど乾 固させる。冷却後混酸 $10 \mathrm{cc}$ を加え, さらに水約 $25 \mathrm{cc}$ で 稀釈してから過沃素酸カリ $0.2 \mathrm{~g}$ を加えて加熱沸騰さ せ，以下上述の方法と同様に操作する。

過マンガン酸カリ溶液 $50 \mathrm{mg} / \mathrm{l}$ の中性液 $(\mathrm{pH} 7.04)$ および酸性液 ( $\mathrm{pH} 4.50$ 硫酸酸性) に試料を浸漬した 結果, いずれの場合にも $0.078 \mathrm{mg} / \mathrm{g}$ sample の $\mathrm{Mn}$ が 定量され，この值は浸漬前後の溶液濃度差から求めた值 とほとんど一致するが，前者の值がわずか小さい。この ように過マンガン酸カリ溶液を作用させた試料には水洗 滌によつては離脱しないMnが定量され，これがどのよ らな形で存在するかは次の電子回折によつて決定した。

また試料 $2 \mathrm{~g}$ を醋酸アンモン $25 \%$ 加熱溶液 $100 \mathrm{cc}$ 中 で振湯，液中の硫酸根を定量した結果，過マンガン酸カ リ溶液に浸漬前には全く硫酸根を認めないが, 浸漬後に は $6 \mathrm{mg} / l$ の $\mathrm{SO}_{4}^{--}$が認められた。従つて方鉛鉱は過 マンガン酸カリ溶液によつてまず軽微な素面酸化をうけ 硫酸鉛に変化するものであろう。

\section{$4 \cdot 2$ 電子回折結果}

朝日試料を試験直前に䢃開して結晶片 $(4 \times 4 \times 2 \mathrm{~mm})$ をとり出し, 過マンガン酸カリ溶液 $300 \mathrm{mg} / l$ の $50 \mathrm{cc}$ 中 に $30 \mathrm{~min}$ 浸漬, 純水でよく洗涤の後, 水滴を沪紙で 吸いとり，自然乾燥してから電子回折を行なつた。これ と比較する目的で新鮮な䢃開面, エメリ一研摩面および 純水に漫漬した試料の電子回折も行なつた。新鮮な屖開 面は著しい疎水性を示して強く水を注じくが，過マンガ ン酸カリ溶液に浸漬後の試料では強度の親水性に変化し ていることが肉眼的に認められる。

電子回折像の撮影汇は JEM-5G 型電子顕微鏡(日本 電子光学製）を用い，加速電圧を $80 \mathrm{kV}$ とした。それぞ れの試料について 6 個の結晶片を準備し, 同一結晶片に ついても毎回視野をかえ, 計 12 視野を撮影した。また 試料 2 視野毎に標準物質の $\mathrm{Au}$ 簿を撮影し, 撮影中の 霄圧変動の補整に供し, この Au像を解析する際には精 密格子常数 $a_{0}=4.0786 \AA^{7 \mathrm{a})}$ の值を適用した。しかし, 標淮物質として使用する $\mathrm{Au}$ 䇴の純度が問題で, 例えば Ag などを固溶している場合には結晶構造にヒズミを生 じ，したがつて回折に用いる前に他の標準物質で較正し

* $\mathrm{HNO}_{3}(1: 1) 100 \mathrm{cc}$ 飞 $\mathrm{H}_{3} \mathrm{PO}_{4} 100 \mathrm{cc}$ を混合したるの。 

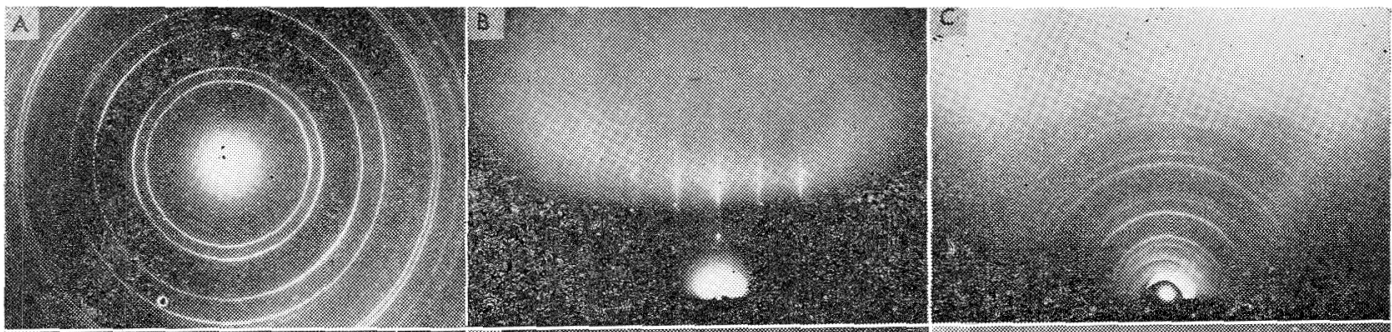

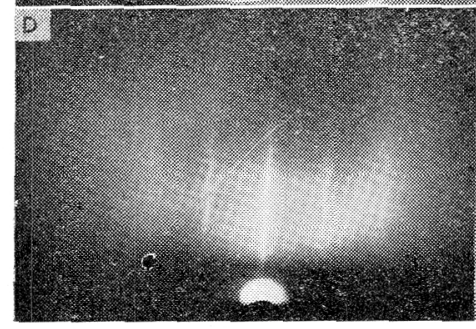

A : 摽值会箔 $\mathrm{F}$ ：過マンガン酸カリ溶液(酸性)に浸漬した通

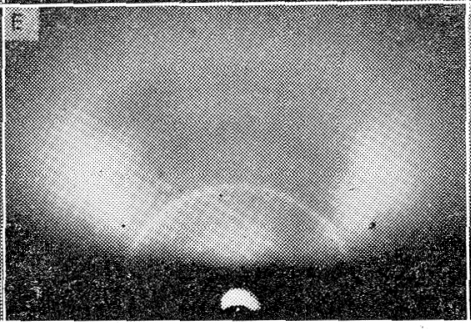

$D$ ：純水に浸濆した面

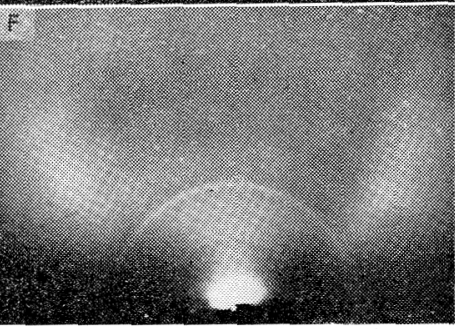

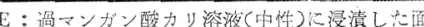

第5図電子回折写真

ておく必要がある。本実験ではMgを空気中で然焼させ その白煙 $(\mathrm{MgO})$ 它 $\mathrm{Au}$ 䈏で受け, $\mathrm{Au}$ と $\mathrm{MgO}$ の回 折線を同一写真に撮影し，この雨者を比較した。

第 5 図の $\mathrm{A} \sim \mathrm{F}$ に標準 $\mathrm{Au}$ 䈃, 新鮮な憵開面, エメ リ一研摩面，純水に浸漬した面，中性および酸性の過 マンガン酸カリ溶液に漫漬した面の電子回折像を示し た。新鮮な䢃開面では方鉛鉱の回折点とStreak Pattern があらわれ，この面を細がメリーペーパで研摩する とそれぞれの $(h k l)$ の回折点が連続して明瞭な DebyeScherrer 像を示す。新鮮䢃開面を純水中に $30 \mathrm{~min}$ 浸清 し，水滴を沪紙で吸いとり自然乾燥した面では，譬開面 记認められた回折点が消失し，極くかすかな方鉛鉣の Debye-Scherrer 像が観察される。このように，方鉛鉱

第 4 表 新鮮䢃開面, 純水浸漬面㧍よび エメリ一研摩面の原子面間隔

\begin{tabular}{|c|c|c|c|c|c|c|c|c|}
\hline \multicolumn{2}{|c|}{ 新鮮䢃開面 } & \multicolumn{2}{|c|}{ 純水浸清面 } & \multicolumn{2}{|c|}{ エメリ一研摩面 } & \multicolumn{3}{|c|}{$\mathrm{PbS} 7 b)$} \\
\hline$d(\AA)$ & $I / I_{1}$ & $d(\AA)$ & $I_{/} I_{1}$ & $d(\mathrm{~A})$ & $I / I_{1}$ & $d(\AA)$ & $I / I_{1}$ & $h k l$ \\
\hline $\begin{array}{l}1.74 \\
1.71 \\
\\
1.16 \\
1.09 \\
0.97 \\
0.95\end{array}$ & $\begin{array}{c}\mathrm{vs} \\
\mathrm{s} \\
\mathrm{m} \\
\mathrm{m} \\
\mathrm{w} \\
\mathrm{w}\end{array}$ & $\begin{array}{l}2.95 \\
2.08 \\
1.77\end{array}$ & $\begin{array}{l}V w \\
V w \\
V W\end{array}$ & $\begin{array}{l}3.39 \\
2.96 \\
2.10 \\
1.79 \\
1.73 \\
1.33 \\
1.21 \\
1.15 \\
1.00 \\
0.94 \\
0.90 \\
0.83 \\
0.30\end{array}$ & $\begin{array}{l}\mathrm{m} \\
\mathrm{s} \\
\mathrm{vs} \\
\mathrm{m} \\
\mathrm{m} \\
\mathrm{m} \\
\mathrm{m} \\
\mathrm{vw} \\
\mathrm{w} \\
\mathrm{vw} \\
\mathrm{vw} \\
\mathrm{vw} \\
\mathrm{vw}\end{array}$ & $\begin{array}{l}3.429 \\
2.969 \\
2.099 \\
1.790 \\
1.714 \\
1.327 \\
1.212 \\
1.1424 \\
1.0489 \\
1.0034 \\
0.9893 \\
0.9386 \\
0.9050 \\
0.8312 \\
0.8232\end{array}$ & $\begin{array}{r}84 \\
100 \\
57 \\
35 \\
16 \\
17 \\
10 \\
6 \\
3 \\
5 \\
6 \\
4 \\
2 \\
3 \\
3\end{array}$ & $\begin{array}{l}111 \\
200 \\
220 \\
311 \\
222 \\
420 \\
422 \\
511 \\
440 \\
531 \\
600 \\
620 \\
533 \\
711 \\
640\end{array}$ \\
\hline
\end{tabular}

第 5 表 過マンガン酸カリ溶液作用時の回折像

\begin{tabular}{|c|c|c|c|c|c|}
\hline \multicolumn{2}{|c|}{$\mathrm{pH} 7.0$} & \multicolumn{2}{|c|}{$\mathrm{pH} 3.5$} & \multicolumn{2}{|c|}{ 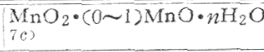 } \\
\hline$d(\AA)$ & $I / I_{1}$ & $d(\AA)$ & $I / I_{1}$ & $d(\AA)$ & $I / I_{1}$ \\
\hline $\begin{array}{l}2.46 \\
1.42\end{array}$ & $\underset{\mathrm{v} s}{\mathrm{~m}}$ & $\begin{array}{l}2.42 \\
1.42\end{array}$ & s & $\begin{array}{l}2.45 \\
1.40\end{array}$ & $\begin{array}{l}100 \\
100\end{array}$ \\
\hline
\end{tabular}

は純水中に浸漬しただけでも表而の性状は変化するもの で，水中漫漬によつて譬開面の有していた平滑さが失わ れて行くことが判るが，他物質の生成は認められない。 これらの写真から原子面間隔を算出すれば第 4 表の通り 方鉛鉣以外の物質は全く認められない。

次に過マンガン酸カリの中性液と酸性液 $(\mathrm{pH} 3.5)$ に 浸清した後の面には，いずれも Manganese Oxide Hydrate $\mathrm{MnO}_{2} \cdot(0 \sim 1) \mathrm{MnO} \cdot n \mathrm{H}_{2} \mathrm{O}$ の $2.45 \AA$ と 1.40 $\AA$ の顕著な回折線があらわれ，方鉛鉣の回折点は全く 消失している。したがつてさきの化学分析で試料中に定 量された Mn はこの形で鉱物表面に固定していること が分つた。第 5 表にこの回折像の原子面間隔を示した。

この新生成物の回折線は天然に虐出した Wad の回折

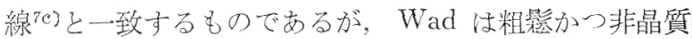
に近い含水マンガン酸化物の総称で，勿論その鋝物内容 や化学成分も一定しない。方鉛鉱表面に認められた Wad 様物質の生成機構については現在さらに検討老続けてい る。

\section{5. 考察}

固体の濡れの性質坴交らわすに位触角の测定が普通 に行われるものであるが，その測定自体は精密な方法で 実施されても次のような理由によつて測定值に相当の変 動が伴ら。すなわち（a）固体の表面エネルギーは非常 に不均一，（b）新鮮な活れのない試料の調整加困難, (c) 接触角のヒステリシス現象老伴うことなどである。 (a)については少数の測定值では不安定であるから数多 くの測定を行う必要老生ずる。筆者は20 試料片につい てそれぞれ 2 测点をとり 40 㑑の测定值を集計する一方 最大および最小のばらつきを含めたものを測定結果とし てとり扱つた。しかし全部で 37 陚料について約 1,500 
回の測定結果を総合してみると，算術平均を代表值とし てとり扱つても不合理でないことが経験的に知れた。 （b）については酸化物の生成あるいは他物質の吸着乃至 付着などによつて污染され易いものであるが，辟開直後 に電子回折を行つて他物質による污染がないことをあら かじめ確認しておいた。（c）については摩擦説，吸着説， 粗面説などによつて説明されているが $8^{211)}$ ，笔者が適用 した拡大映像法では，水滴が小さければ水滴のおき方に 無関係に前進接触角を与えるもので ${ }^{22)}$ ，この場合水滴の 径は $1.5 \mathrm{~mm}$ 以下であれば充分であると報告されてい $\varpi^{4,5)}$ 。

測定は各試料とも新鮮暨開面とエメリ一研摩面につい て行つたが，いずれの場合も前者の值が大きい結果を得 た。同一化学組成であつても測定面の性状によつて濡れ の程度は異なるもので，粗面接触角の減少はこれまでも 報告されている通りである ${ }^{11) 。 ~}$

方鉛鉱の接触角はこれまでも多くの人によつて測定さ れているが，その数例を一括すれば第 6 表の通りで，測 定面の性状の差異もあるが，相当のばらつきが見られ る。これはさきに挙げた理由によつてばらつくものであ るが，筆者の場合各試料について数多くの測定值を集計． してもな扝試料による差があらわれ，この現象は試料の 化学成分とくに微量成分に支配されることが見出され た。すなわち，エメリ一研摩面で銀量の少ない朝日試料 (Ag 196g/t) は 79 ，銀量の多い田老試料 (Ag 2,048g /t ） $71^{\circ}$ で両者の差が認められる。このような化学 成分による濡れの差は浮選試験の結果にもあらわれ $\mathrm{Ag}$, $\mathrm{Bi}$ などの微量成分の多いものは浮遊し難いことが認め られた。

しかし，さきに報告した通り $\mathrm{Ag}$ および $\mathrm{Bi}$ の一部 は方鉛鉱中に固溶し，残りは微小鉱物の形で包裹される もので，各種本邦産方鉛鉱について化学分析，精密格子 常数の測定および顕微鏡下の統計的観察による微小包裹 鉱物量の測定を行つた結果を総合すると，方鉛鉱中には 約 $2,000 \mathrm{~g} / \mathrm{t}$ の $\mathrm{Ag}$ が固溶し得ることが分つた*。また 固溶成分の増加にしたがつて方鉛鉱の結晶格子が収縮す ることを認めるので，格子常数を測定すれば固溶量を推 算することが出来よう。さきに測定した格子常数》と接 触角を対比すると，格子七ズミが大きくなるにしたがつ て方鉛鉱は濡れやすい傾向を示す。したがつて方鉛鉱に 含まれる微量成分の中で，固溶体の形をとるものがまず 濡れの性質に影響を与えるものと考えられる。しかし固 溶限以上に $\mathrm{Ag}, \mathrm{Bi}$ を含む試料では当然包裏析出鉱物 の影響があらわれるであるらから，これらは別途検討す る必要がある。

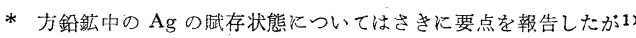
詳細比ついては别に発表したい。
第 6 表 方鉛鉣の接触角一覽表

\begin{tabular}{|c|c|c|c|}
\hline 定 & $\theta$ & 測定面の性 状 & 交献 \\
\hline 斉藤 & 83 & 朝日産，新鮮冐 & 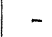 \\
\hline $\begin{array}{l}\text { I. W. Wark and A. B. Cox } \\
\text { (1934) }\end{array}$ & $\begin{array}{r}19 \\
0\end{array}$ & polished surface & 13 \\
\hline $\begin{array}{l}\text { F. E. Bartel and G. E. } \\
\text { Batch (1935) }\end{array}$ & 90 & freshly cleaved galena & 17 \\
\hline $\begin{array}{l}\text { S. G. Mokruskin and N. } \\
\text { Demenev (1937) }\end{array}$ & 78 & - & 14 \\
\hline $\begin{array}{l}\text { E. Kneen and W. W. } \\
\text { Benton (1937) }\end{array}$ & 90 & fresh cleavage & 4 \\
\hline M. E. Wadswarth et al & $<20$ & polished galena & 15 \\
\hline $\begin{array}{l}\text { J. H. Walsh and T. R. } \\
\text { Ingraham (1957) }\end{array}$ & 0 & 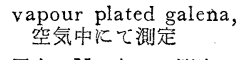 & 16 \\
\hline 同上 & 0 & 同上, $\mathrm{N}_{2}$ 中にて測定 & 16 \\
\hline
\end{tabular}

これまでは方鉛鉱浮選における過マンガン酸カリの抑 制効果は漠然とその酸化作用によるものと考えられてい たが，電子回折の結果から明らかなようにこれは鉱物表 面の新しい生成物によることが分つた。この新生成物の 回折像には方鉛鉱その他の回折像が全く認められないの で，生成物の厚さはある程度に達しているものと考えら れ，また瓶開面上の特定な方向に生長するものでなく， 全く乱雑な結晶配列をなしていることを認める。この生 成物は水の洗浄によつては離脱するようなことはないが 沪紙で強く拭うと除去することが出来るので，これは単 に方鉛鉱表面に付着しているものでなく，ある強さの結 びつきをなしているものであろう。過マンガン酸カリ作 用後の試料からは洗浄によつて除去出来ない Mnが定量 され，これが Manganese Oxide Hydrate の形で存在 する。

一方過マンガン酸カリ $50 \mathrm{mg} / l$ で条件付与した試料は KEX $30 \mathrm{mg} / l$ を添加しても゙ほとど浮遊しないが，こ 学を醋酸アンモン $25 \%$ 溶液で洗浄し再び KEX $30 \mathrm{mg} / \mathrm{l}$ で浮選すると著しく浮遊性を増し，ほぼ新鮮試料と同程 度の值を示す。また条件付与後の方鉛鉱は金属光沢を失 いかつ変彩しているが，醋酸アンモンの洗浄で全く原試 料の光沢および色調に復元する。このようなことは方鉛 鉱の表面に硫酸鉛の生成を暗示するもので，さきに述心゙ た通り洗浄後の醋酸アンモン中に定量された硫酸根はこ れに対応寸るものであろう。

したがつて過マンガン酸カリ溶液の方鉛鉱に対する作 用機構に対してはまず，

$$
\begin{aligned}
& 2 \mathrm{KMnO}_{4}+\mathrm{H}_{2} \mathrm{O} \rightarrow 2 \mathrm{KOH}+2 \mathrm{MnO}_{2}+30 \text { (アルカリ性〜 } \\
& \text { 中性溶液) } \\
& 2 \mathrm{KMnO}_{4}+6 \mathrm{H}^{+} \rightarrow 2 \mathrm{~K}^{+}+\mathrm{Mn}^{++}+3 \mathrm{H}_{2} \mathrm{O}+50 \text { (酸性溶 }
\end{aligned}
$$
液)

の割合で軽微な表面酸化が行われて硫酸鉛を生じ，この 表面にさらに新結晶体を生成するものと考えられる。

\section{6. 総 括}

産状の異なる本邦産方鉛鉱の接触角を拡大映像法によ 
つて測定した結果，この濡れは測定面の物理的性状や化 学成分に影響され，さらに抑制剤を作用させた場合など には著しい変化が認为られた。また抑制剤作用後の鈗物 表面には電子回折によつて新しい結晶体の生成が確認さ れ，こ礼まで漠然と酸化によるものと考允られていた抑 制剂の作用機構化新しい解釉をなすことが出来た。

（1）接触角法表面粗度に支配され，辟開面ではエメ リ一研摩面より常に大きい值を得る。

（2）接触角注化学成分上くに Ag に上つて変動し， $\mathrm{Ag}$ の増加にしたがつて隇少の傾向を示す。

（3）過マンガン酸カリ溶液を作用させると，接触角 はその濃度汇ほぼ反比例的に变化する。

（4）過マンガン酸カリ溶液によつて方鉛鉱はまず軽 微な酸化をらけ, この酸化物の表面にさらに Manganese Oxide Hydrate $\mathrm{MnO}_{2} \cdot(0 \sim 1) \mathrm{MnO} \cdot n \mathrm{H}_{2} \mathrm{O}$ が生成され る。

\section{謝辞}

本研究を実施するに㐫たり三井金属鉣業株式会社中央 研究所徳永惊所長, 三野英彦次長注絶光ざる御指導と御 鞭韃を賜わり，高林副社長恃発表を許可された。これら の各位に厚く扮礼を申し上げたい。

\section{参考 文献}

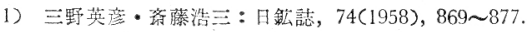

2) 三野英彦・䆧藤浩三：日航誌，75 (1959)，917～922

3) 日本化学会: 実験化学講座, 7 界面化学, (昭和 31 年), $71 \sim 88$ 。

4) Erick Kneen and W. W. Benton: J. Phys. Chem. 41 (1937), 1, 195 1, 203.

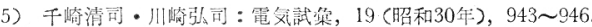

6) E.B.Sandell: Colorimetric Determination of Traces of Metals, New York, (1950), 2nd Ed., 433 434.

7) A.S.T.M. : Index to the X-Ray Powder Data File, (1958). 4-0784a) ; 5-0592b) ; 2-1070c).

8) N. K. Adam and G. Jessop: J. Chem. Soc., 127 (1925), $1,863 \sim 8$.

9) F, E. Bartel and A. D. Wooley: J. Am. Chem. Soc, 55 (1933), 3,518 27.

10) F. E. Bartel and C. W. Bjorklund: J. Phys. Chem., 56. (1952), 453 7

11) R. N. Wenzel : Ind. Eng. Chem., 28 (1936), 988 94.

12) G. L. Mack: J. Phys. Chem,, 40 (1936), 157 67.

13) I. W. Wark and A. B. Cox: Trans, A.I.M.E., 112 (1934), 189 232.

14. S. G. Mokruskin and N. Demenev: J. Phys, Chem. (U.S.S R.), 6(1937), 1,066 70 ;Chem. Abs., 31 (1937), 18.

15) M. E. Wadswarth, R. G. Conrady and M. A. Cook: J. Phys. Colloid. Chem, 55 (1951), 1,219 30.

16) J. H. Walsh and T. R. Ingraham.: Canad. Mining and Met, Bull, 50 (1957), 674 7.

17) F. E. Bartel and G. B. Batch: J. Phys. Chem., 39 (1935), $11 \sim 23$.

\section{新らしい浮選機 2 種}

\section{Cyclo-Cell 浮選機}

第 1 図は Heyl \& Patterson 社 によつて考案された Cyclo-Cell と 呼ばれる珍らしい浮選機である。水 の高速ジェットによつて中空の円錐 が形成され，その水はセルのパルプ 液面下に排出忠れる。空気の流机が このジェットの中空部の中央に導入 さ机ると，その空気は円錐形のスプ

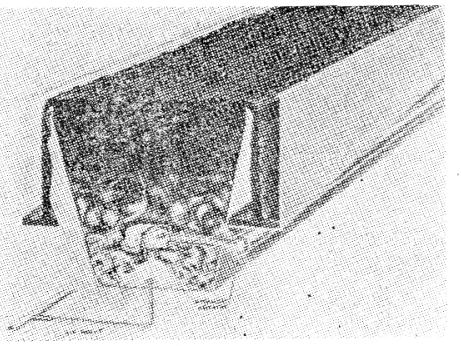

第 1 図
レーを高通過してパルプ中に噴出し， との時に微細な気泡に粉砕されて浮 上する。微細気泡の形成と相なつて 水之空気粉砕の作用比年㹂拌效果 が気泡と鉱粒の揬着に持通な采件を 生两出拮結果，速い浮選が行なわれ るという。

\section{Hollingsworth 浮選機}

Wellman-Lord Engineering 社 によつて発表された Hollings worth 浮選機(符 2 図) はフロ13゙州 のリン鉣地带でリン鉱石の浮選に使 用されている。この浮選機の採用に よつてリン鎕の実收率が約 10\% 向 上したと同社ではいらている。

\section{(井上外志雄)}

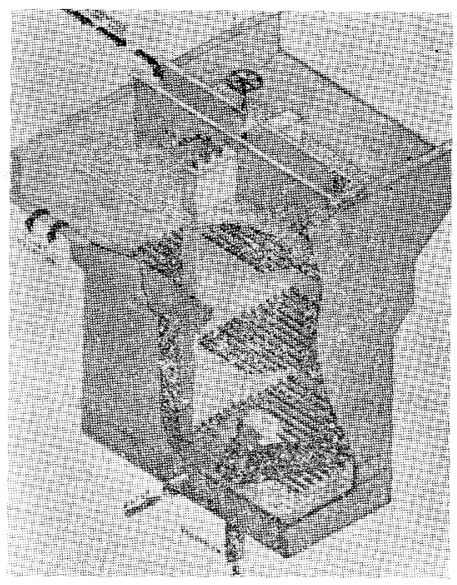

第 2 図 